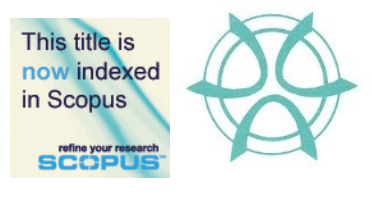

PLANNING MALAYSIA:

Journal of the Malaysian Institute of Planners

VOLUME 18 ISSUE 2 (2020), Page 231 - 242

\title{
ANALYSING COMMUNITY PERCEPTIONS ON INCENTIVE STRATEGIES IN SAFEGUARDING A MALAY HERITAGE VILLAGE: THE CASE OF KAMPUNG MORTEN, MELAKA
}

\author{
Indera Syahrul Mat Radzuan ${ }^{1} \&$ Yahaya Ahmad ${ }^{2}$ \\ ${ }^{1}$ Department of Real Estate Management, Faculty of Technology Management \\ \& Business \\ UNIVERSITI TUN HUSSEIN ONN MALAYSIA \\ ${ }^{2}$ Department of Architecture, Faculty of Built Environment UNIVERSITY OF \\ MALAYA
}

\begin{abstract}
Over-commercialism and the threats posed by uncontrolled development have slowly been eroding the cultural heritage stock, especially in the case of the traditional settlements. This paper reveals the community perceptions and feedbacks on the incentives given in safeguarding the uniqueness of a Malay heritage village known as Kampung Morten in Melaka. This study set out to determine the overarching question, which was, whether the incentive programmes formulated for the community have been found to be suitable to the aspirations and 'real' needs of the local communities. Mixed method approaches were used in this study which included document reviews, observations, structured interviews and a questionnaire survey; and involved the residents living in the village. This study evaluates the findings concerning the present policy framework, for understanding and managing the cultural heritage incentives programme in safeguarding the heritage village to establish a sustainable community. This paper has been able to reveal several issues on the conservation incentives policy, most notably of which is the incompatibility of the local communities' needs with the programme outcomes.
\end{abstract}

Keywords: heritage village, Malay, incentive strategy, sustainable communities, community engagement, community perception.

\footnotetext{
${ }^{1}$ Senior Lecturer at Universiti Tun Hussein Onn Malaysia. Email: syahrul@uthm.edu.my
} 
Indera Syahrul Mat Radzuan \& Yahaya Ahmad

Analysing Community Perceptions on Incentive Strategies in Safeguarding a Malay Heritage Village: The

Case of Kampung Morten, Melaka

\section{INTRODUCTION}

Effective incentives are essential in order to achieve the preservation principle for the present and the future generations. According to Meng (2015), incentivisation is generally recognized as a strategy of addressing programme performance; and thus, is a key aspect of the economics of any historic heritage. Incentives can be regulatory or non-regulatory, and may include a wide range of policies and methods. Incentive policies are tools to motivate the historic property owners or investors to retain their buildings or sites, and their delivery mechanisms vary from country to country.

It is crucial to understand the full potential of heritage village as valuable resources and contribute to sustainable development in a dynamic way. Given the complexity of the concept of heritage village, this research investigates the challenges and conflict between conservation and urbanization in the scope of living heritage. This paper presents an analysis on community perceptions, and how the incentives strategy works in safeguarding the uniqueness of a Malay heritage village known as Kampung Morten in Melaka.

\section{LITERATURE REVIEW}

A good amount of literature has discussed the dilemma and survival of the heritage villages across the Asian region (see Yeoh and Huang (1996); Sharifah Mariam Alhabshi (2010); Lih (2005) and Norsidah (2020). Over-commercialism and the threats posed by uncontrolled development have slowly been eroding the cultural heritage stock, especially in the case of the traditional settlements. The development and modernization processes in these regions in the 1980s have especially resulted in changes to the lifestyles as well as the social and moral values of the populations (Jones, 1997).

\section{What Are Incentives?}

Many works of literature have encompassed the incentives provision in diverse disciplines such as researches in finance by Read (2005), wildlife conservation by Hadlock and Beckwith (2002), forest management by Kumar (2007) and business by Goetz (2010). However, very few researchers have touched on heritage areas. As observed, there has been little or no research into the nature and impact of these incentives and how they might be integrated into heritage management strategies. However, only a few studies have been found in literature that have dealt with the incentives provision strategy from the perspective of cultural heritage preservation. Roddewig (1987) has been one of the few commentators who has written explicitly about the use of incentives in the preservation of historic areas. He pointed out how some of the ways in which incentives can assist the conservation of historical areas. In his view, incentives have two specific roles in the conservation process: (1) to generate more 
rehabilitation of historic structures than would be possible, presumably, through other forms of government action, and (2) to provide a reasonable economic return to owners of buildings protected and restricted by laws.

\section{Heritage Village and A Living Heritage}

The term 'heritage village', which is the subject of this study, is defined as a traditional neighbourhood community or a specific district with historic significance, where both, the physical characteristics and its inhabitants, carry on with the living traditions, skills and other cultural practices. Heritage villages are different from single monuments, ensembles of historic buildings or pure natural heritage sites, where fewer social activities are involved.

According to Orbasli (2002), only in the second half of the twentieth century has there been a growing appreciation and understanding of living heritage, its recognition as being 'heritage', and a desire for area-based conservation. This has coincided with the birth of the Venice Charter that came into effect in 1964 and contained principles governing architectural conservation and restoration. Even though the human dimension of the value of heritage has been clearly recognized in the Charter, no direct reference has been made to living heritage.

Therefore, the United Nations Educational, Scientific and Cultural Organization (UNESCO) Convention Concerning the Protection of the World Cultural and Natural Heritage, which came into effect in 1972, made direct reference to community life. Article 5 suggested that each state which had signed up for this convention should 'adopt a general policy which aims to give cultural and natural heritage a function in community life, and to integrate heritage protection into comprehensive planning programmes' (Miura, 2005). Malaysia ratified the convention on 7 December 1988. Nonetheless, since 1992, the World Heritage programme increasingly focused on traditional knowledge, and the role of local communities in protecting and managing mechanisms. Additionally, the programme has fostered synergies between modern science and local knowledge, which are relevant to both cultural and natural heritage (Netherlands National Commission for UNESCO, 2014). Since then, further emphasis has been placed on the intrinsic relationship between culture and nature, people and places, and cultural diversity. Considering all of this evidence, it seems that the incentives provision is an important tool in safeguarding the living heritage as well as in creating a community's sense of place in accomplishing the sustainable community approach.

\section{BACKGROUND OF KAMPUNG MORTEN}

Kampung Morten is a traditional Malay village situated in the middle of Melaka city, just outside the designated UNESCO's World Heritage Site. The village, with a population of over 600 , is considered one of the most outstanding Malay 
Indera Syahrul Mat Radzuan \& Yahaya Ahmad

Analysing Community Perceptions on Incentive Strategies in Safeguarding a Malay Heritage Village: The Case of Kampung Morten, Melaka

enclaves, with the meandering Melaka river flowing besides it (Figure 1). The Melaka State Government in 1988 gazettement had declared the village as a traditional Malay heritage village. This recognition was under the Melaka state's Preservation and Conservation of Cultural Heritage Enactment of 1988 (Abdul Aziz, 2017). It is a fine example of a typical Malay village which is locked in the midst of modern development but is still lingering on with its own past history. The demographic profiles of Kampung Morten are shown in Table 1 below.

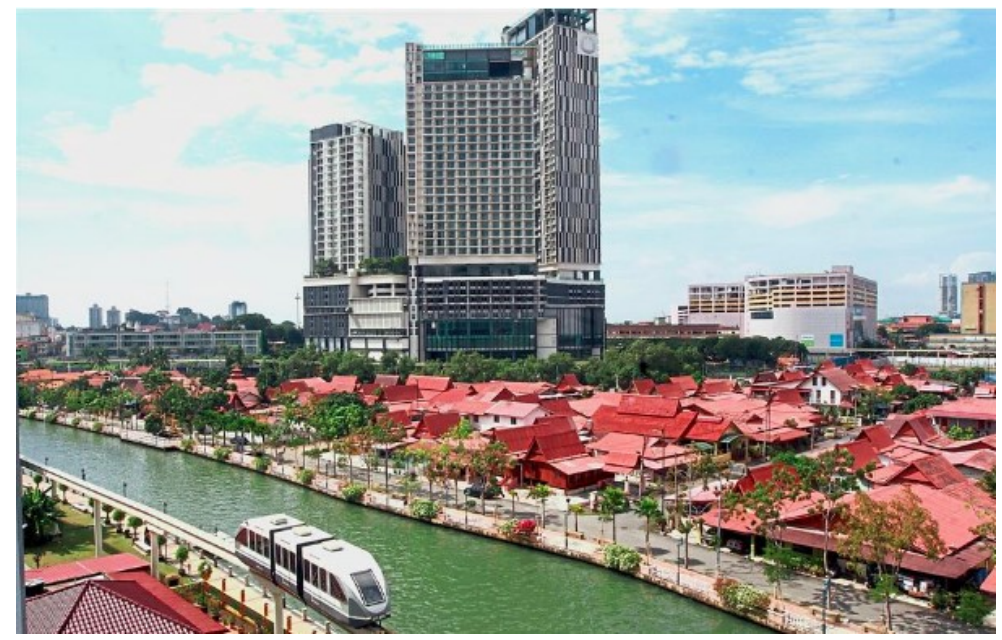

Figure 1: Kampung Morten still retains its traditional Malay kampung charm even though it is locked in the midst of modern development Source: Murali (2018)

Table 1: Demographic profile of Kampung Morten

\begin{tabular}{ll}
\hline Demographic Profile & Numerical Data \\
\hline Population & 630 \\
Number of households & 98 \\
Total area & 12 acre \\
Number of incentive recipients & 80 \\
Number of samples & 45 \\
\hline & Source: Author (2016)
\end{tabular}

\section{METHODOLOGY}

A mixed methods approach of concurrent triangulation design was used in this study, which included the usage of document reviews, observations, structured interviews and a questionnaire survey, involving the residents living in the respective site. Stratified sampling was used in the questionnaire survey to classify the specific residents, based on the residents who received the heritage 
PLANNING MALAYSIA

incentives from the authorities. The survey and interview data were collected in March 2014 and October 2016

\section{Incentives Provision}

Since the year 2000, about RM2 million has been allocated by the Federal Government, via the Ministry of Culture, Arts and Tourism (recently known as the Ministry of Tourism, Arts and Culture), to standardise the roofings of more than 80 houses in Kampung Morten. Besides that, beautification programmes have also been carried out to enhance its aesthetic appeal. The most significant aid has been for house renovations, where selected old Malay houses have undergone renovation mainly to their main structure, walls, windows, roofs and stairs (Figure 3).

As part of revitalizing the landscape efforts by the Melaka Historic City Council (MBMB), steel railings with attractive designs were erected along the facade facing the Melaka River, for the safety of the villagers and visitors. Technical assistance for the restoration of houses involved the maintenance and repair of their structures and facades. This was administered by the Melaka Museums Corporation using the funding allocated by the Conservation and Restoration Trust Fund from 2001 to 2010. The restoration project benefitted the recipient house owners. A majority of them received financial support, which was approximately about RM10,000.00 each, in the year 2001. The highest sums were distributed in 2010 and 2008, which had amounted to RM64,550.00 and RM46,500.00 respectively.

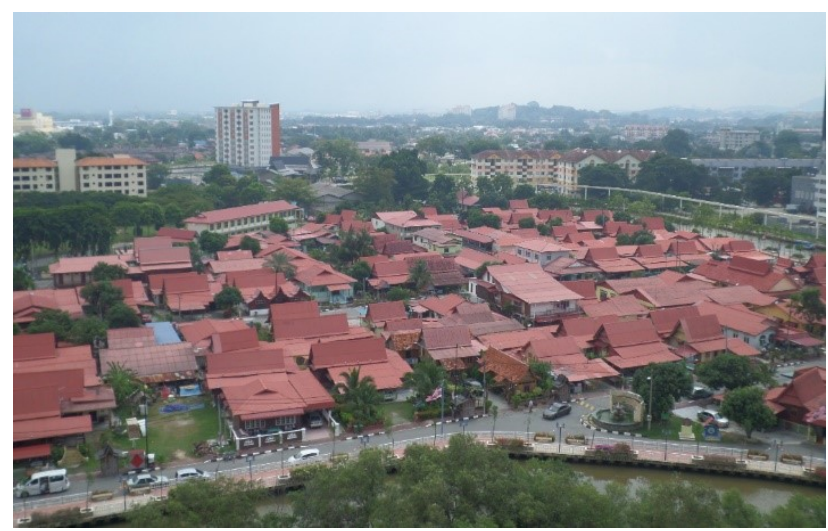

Figure 3: Most houses in Kampung Morten have undergone major renovations for the main structure, walls, windows, roofs and stairs since the year 2000

Source: Author (2018)

Additionally, in 2008, the Melaka Historic City Council, through their Engineering Department, granted the Morten Village more supporting funds for the repair and beautification programmes. Funds amounting to about RM3 
Indera Syahrul Mat Radzuan \& Yahaya Ahmad

Analysing Community Perceptions on Incentive Strategies in Safeguarding a Malay Heritage Village: The Case of Kampung Morten, Melaka

million were allocated for house repairs in the Morten Village, involving 80 units of properties along the Melaka river. The assistance was provided largely in the form of exterior repairs, roof maintenance and structural defects. Moreover, the beautification programme has also involved the installation of "light-emitting diode (LED) rope lights" on the roof-tops of the 80 units of houses, with a total allocation of RM248,500.00, which was done in order to showcase an outstanding view of the Malay kampung during the night time. In 2009, an incentive with a total allocation cost of RM990,761.00 was provided to upgrade the drainage, landscape and pedestrian walkways by installing decorative streetlamps.

\section{DATA ANALYSIS AND MAJOR FINDINGS}

To measure the effectiveness of the incentives programme, this research employed the Bennett's programme evaluation method (Bennett, 1975). According to the model, the hierarchy of evidence for programme evaluation can be classified into seven levels, namely, the programmes' resources, activities, participation, reactions, learning, actions and impacts (Figure 3).

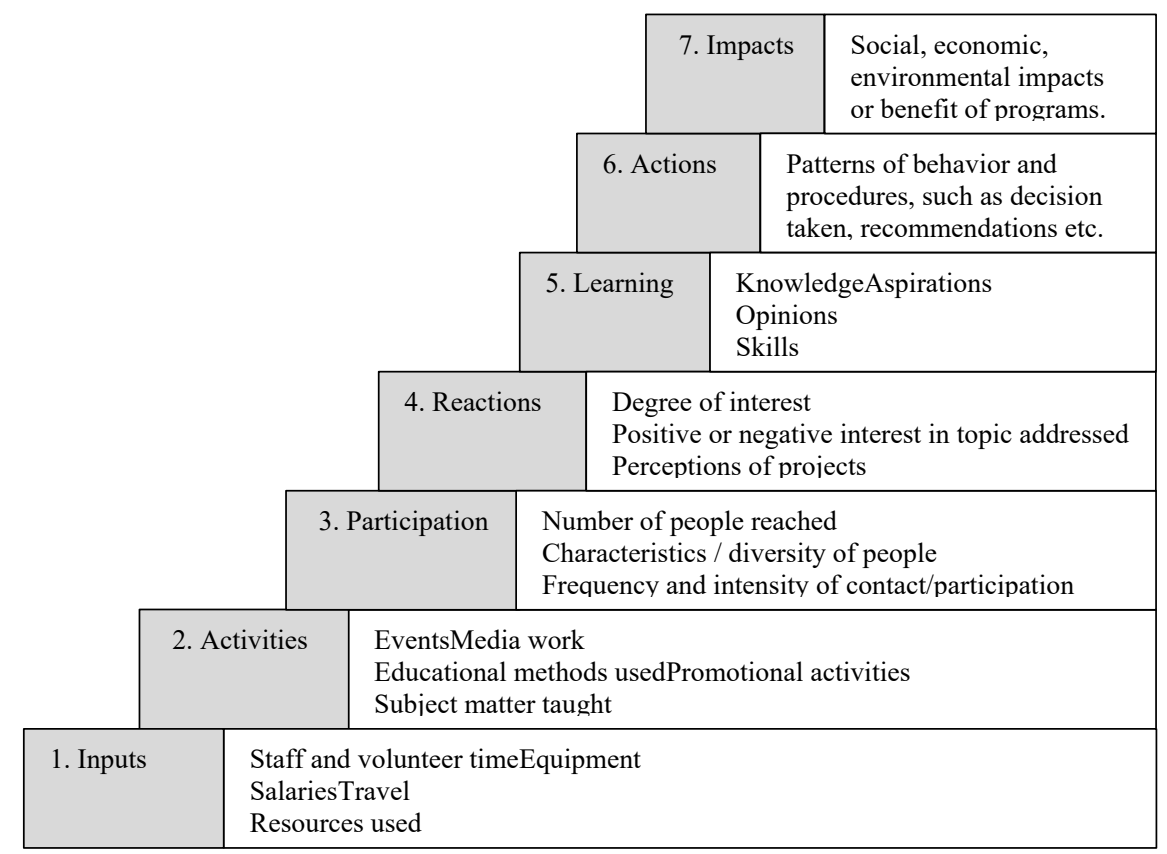

Figure 3: Hierarchy of programme evaluations

Source: Bennett and Rockwell (2004)

According to Roberts (2007), in order to measure incremental change during the programme implementation, Bennett had come up with a hierarchy that could show the causal links between the steps from inputs to outcomes; and could also show where along the continuum of change, had an extension programme reached 
its delivery. This study set out to determine the overarching question, which was, whether the incentive programmes formulated for the community have been found to be suitable to the aspirations and 'real' needs of the local communities. Data was analysed using the Statistical Package for Social Sciences (SPSS) software and descriptive statistics. It evaluated the findings concerning the present policy framework, for understanding and managing the cultural heritage incentives programme in safeguarding the heritage village to establish a sustainable community.

In order to facilitate an average estimation of the satisfaction level, the values were grouped according to three equal categories (Mastor \& Ibrahim, 2012). The cut-off point was calculated from the difference between the mean highest value and the minimum value on three degrees that represent the number of levels, using the formulae - $((5-1) / 3=1.33)$. Thus, the degree values of the incentives programme evaluation are shown in Table 2.

Table 2: Degrees of the incentives programme evaluation and residents' needs for the tangible and intangible heritage

\begin{tabular}{|c|c|c|}
\hline Evaluation & Degree & Level \\
\hline \multirow{3}{*}{$\begin{array}{l}\text { Incentives } \\
\text { programme } \\
\text { (5-point Lickert } \\
\text { scale) }\end{array}$} & $1.00-2.33$ & $\begin{array}{l}\text { Low (Level of incentives programmes } \\
\text { evaluation is at low level) }\end{array}$ \\
\hline & $2.34-3.67$ & $\begin{array}{l}\text { Moderate (Level of incentives programmes } \\
\text { evaluation is at moderate level) }\end{array}$ \\
\hline & $3.68-5.00$ & $\begin{array}{l}\text { High (Level of incentives programmes } \\
\text { evaluation is at high level) }\end{array}$ \\
\hline $\begin{array}{l}\text { Needs for tangible } \\
\text { and intangible }\end{array}$ & $1.00-1.66$ & Low (Level of needs are at low level) \\
\hline $\begin{array}{l}\text { heritage } \\
\text { (3-point Lickert }\end{array}$ & $1.67-2.33$ & $\begin{array}{l}\text { Moderate (Level of needs are at moderate } \\
\text { level) }\end{array}$ \\
\hline scale) & $2.34-3.00$ & High (Level of needs are at high level) \\
\hline
\end{tabular}

Using the five-point Likert scale, respondents were asked whether they agreed or disagreed with the statements pertaining to their satisfaction towards the incentives programme's inputs (how participants perceive the resources of the programme), programme activities (how participants react to the events or activities conducted), programme participation (the extent of the participants involvement), programme reactions (how participants react to the programme's interest), programme learning (to what extent participants acquired knowledge), programme actions (how participants react to the decisions taken) and programme impacts (the overall benefits). Table 3 shows a summary of the mean score and standard deviation of the incentives programme evaluation by the Kampung Morten residents. The mean score ranged from 2.73 to 3.95, with an overall mean of 3.53 . 
Indera Syahrul Mat Radzuan \& Yahaya Ahmad

Analysing Community Perceptions on Incentive Strategies in Safeguarding a Malay Heritage Village: The Case of Kampung Morten, Melaka

Table 3: Mean and level for the incentives programme's evaluation

\begin{tabular}{lccl}
\hline Incentives Programmes & \multicolumn{3}{c}{ Kampung Morten } \\
\cline { 2 - 4 } Evaluation & Mean & $\begin{array}{c}\text { Standard } \\
\text { Deviation }\end{array}$ & Level \\
\hline Programme's Inputs & 3.889 & 1.017 & High \\
Programme's Activities & 3.436 & 1.121 & Moderate \\
Programme's Participation & 3.948 & 0.794 & High \\
Programme's Reactions & 3.511 & 1.203 & Moderate \\
Programme's Learning & 3.496 & 1.216 & Moderate \\
Programme's Actions & 3.659 & 1.133 & Moderate \\
Programme's Impacts & 2.733 & 1.260 & Moderate \\
\hline Total Mean & 3.525 & 0.926 & Moderate \\
\hline
\end{tabular}

Among the seven factors of the incentives programme's evaluations, programme's participation and programme's inputs had the highest mean score with a value of 3.95 and 3.89 respectively, followed by the programme's actions (3.66) the programme's reactions (3.51), the programme's learning (3.50), the programme's activities (3.44), and the programme's impact (2.73). The findings have provided evidence that respondents in Kampung Morten have evaluated the incentives programme's participation, and the inputs recorded were the highest as compared to evaluation indicators from other programmes.

\section{RESULTS AND DISCUSSION}

This study evaluates how the incentives programme has worked, and identifies the impacts and challenges faced by the concerned community in the current scenario. The researcher recorded the following evidence after conducting a series of interviews in Kampung Morten. In this section, a thematic style of reporting was applied, where four broad themes emerged as shown below.

\section{Views on Urbanization and Tourism Impacts}

The respondents were asked on the impacts of urbanisation towards their daily lifestyle. One respondent from the village stated that: "We really miss the 'kampung' environment that we had over the last 40 years. The 'ugly big giant' (the skyscraper) across the river has made our lives uneasy and inconvenient. It has really spoilt the scenery of our 'kampung' which was really pleasant before urbanisation came" (Personal communication, March 12, 2014). The present study raises the fact that urbanisation has somehow disrupted their traditional lifestyle.

When asked whether the tourism activities had benefited the residents, one respondent reported: "We have benefited from the tourism impacts; however, the community is not happy due to the surrounding economic pressures which do 
not benefit us that much" (Personal communication, March 13, 2014). Despite the negative views, one respondent expressed his positive opinion: "There are pros and cons due to the surrounding economic pressures that we currently face. For me it was fine having this kind of development; however, the development should be harmonized with the existing traditional village. I have benefited a lot from this development, especially when people visit and stay at some of our homestays operated in this village. The youngsters can work in the city and I think this is good for our economy too" (Personal communication, October 29, 2016). Interestingly, there was a significant difference between the positive and negative impacts of the tourism activities held in this heritage village.

\section{Views on Public Participation}

When the participants were asked "What kind of participation did the community members have in drawing up the incentives programme for their village?", the majority commented that the initial discussion for the conservation project was made among the leaders and majority of them were not involved. One respondent had highlighted: "The government promised to allocate a sum of money to improve our houses as part of the conservation programme for this village. However, the dishonest contractors have benefited a lot while nothing much has been done in real practice" (Personal communication, October 29, 2016). Another respondent expressed her disappointment and stated: "The contractors working on the project were not competent enough and did not fully understand the principle of conservation. They just did the work for the sake of money, and I still have to use my own money to fix the broken crafted windows" (Personal communication, October 29, 2016). These evidences indicate that there were negative comments about how the financial support for house restoration was manipulated by appointed contractors.

\section{Views on Conservation Works and Monitoring System}

The respondents were also asked on the quality of the conservation works done by the appointed contractors for conservation work at their premises. One respondent commented, "The quality of the workmanship was found to be poor. For instance, after they had finished the renovation, we again faced other problems, where some roofs were leaking; there were gaps in between the timber wall arrangement, and the windows they installed did not fit and could not be closed easily. The poor workmanship is really unacceptable and we are not truly satisfied because they did everything in a hurry. The contractors ignored our feedback on their workmanship" (Personal communication, March 17, 2014).

One respondent pointed out: "We were not given any chance to suggest preferred incentives to the local authority. They had set the policy for us. When the project started, the engineers from the local authority had somehow failed to monitor the work done by the contractors (Personal communication, October 29, 
Indera Syahrul Mat Radzuan \& Yahaya Ahmad

Analysing Community Perceptions on Incentive Strategies in Safeguarding a Malay Heritage Village: The

Case of Kampung Morten, Melaka

2016). Some of the respondents interviewed had stated that the implementation phase was found lacking. It was mentioned that: "When we complained about the quality of the workmanship, nothing was done, and so we could not expect anything from them. When we asked the engineer to sit for discussion, he was absent and sent over his representative. So the situation was truly hopeless for any feedback" (Personal communication, October 29, 2016). These results are likely to be related to the residents' concerns on the lack of monitoring systems led by the authorities in the implementation phase.

\section{Views on Intangible Heritage Educational Needs}

Moreover, when the participants were asked on the intangible heritage educational training focus that they needed the most, the majority commented that: "We need to reintroduce our folk songs such as 'dondang-sayang' and 'joget lambak' and also performing arts like 'silat' back to young generations. However, we have a lack of skilled people to educate the youngsters and we need the heritage-related body to help us in providing the training and support" (Personal communication, March 13, 2014). However, talking about the same issue, one government officer reported that: "We have been facing the death of heirs for inherited intangible cultural heritage in Melaka. The government has been quite active in organizing seminars and workshops (for instance the craftsmanship and several improvement of the heritage-related act). However, the response and participation among the communities has been quite disappointing" (Personal communication, March 21, 2014). However, when we asked the communities "Why did they not participate?". The majority of those who responded to this question felt that: "The younger generations in this village are no longer interested to learn the traditional skills. It takes years to learn those inherited skills. While the majority of us nowadays are exposed to the modern lifestyle" (Personal communication, October 29, 2016). This is the real dilemma facing the residents of the heritage village of the Kampung Morten in Melaka, who are trying their best to preserve their tangible and intangible heritage.

\section{CONCLUSION}

This paper has been able to reveal several issues on the conservation incentives policy, most notably the incompatibility of the local communities needs with the programme's outcomes. The incentives as a driver of sustainability have not been satisfactory enough to provide the strongest effect to the awareness on preserving the cultural heritage values by the local communities. The involvement of the local community has become even more relevant in this regard. The findings of this investigation could be used to determine the success of the community engagement principle applied in the respective case study. 
PLANNING MALAYSIA

Journal of the Malaysia Institute of Planners (2020)

\section{ACKNOWLEDGEMENTS}

The authors would like to thank the Ministry of Education Malaysia for supporting this research under Fundamental Research Grant Scheme for Research Acculturation of Early Career Researchers (FRGS-RACER) Vot No. RACER/1/2019/WAB03/UTHM/1 which is partially sponsored by Universiti Tun Hussein Onn Malaysia and University of Malaya (Project No. PV1102012A).

\section{REFERENCES}

Abdul Aziz, R. (2017). Heritage conservation: Authenticity and vulnerability of living heritage sites in Melaka state. Kajian Malaysia, 35, 39-58.

Bennett, C. (1975). Up the hierarchy. Journal of Extension, 13(2), pp 7-12.

Bennett, C., \& Rockwell, K. (2004). Targeting Outcomes of Programs: A Hierarchy for Targeting Outcomes and Evaluating Their Achievement. Faculty Publications: Agricultural Leadership, Education \& Communication Department. University of Nebraska - Lincoln. Paper 48.

Goetz, K. S. (2010). Encouraging sustainable business, practices using incentives: A practitioner's view. Management Research Review, 33 (11), pp. 1043-1053.

Hadlock, T. D., \& Beckwith, J. A. (2002). Providing Incentives for Endangered Species Recovery. Human Dimensions of Wildlife, 7(3), 197-213.

Jones, A. (1997). Urban conservation issues in Brunei Darussalam: the case of Brunei's water villages. Planning Perspectives, 12(4), 457-475.

Kumar, C. (2007). Perceptions of incentives for participation: insights from joint forest management in India. International Journal of Sustainable Development \& World Ecology, 14(5), 532-542.

Lih, C. Y. (2005). Conservation and change: A Singapore case of urban conservation and development. Paper presented at the 15th ICOMOS General Assembly and International Symposium. Monuments and sites in their setting - Conserving cultural heritage in changing townscapes and landscape, 17-21 Oct. Xi'an, China.

Mastor, S. H., \& Ibrahim, N. (2012). Quality Management (QM) Practices in Facilities Managemant (FM) Organisation: A Case Study in Malaysia. Paper presented at the IEEE Symposium on Business, Engineering and Industrial Applications (ISBEIA) 2012, Bandung, 23-26 Sept.

Meng, X. (2015). Incentive Mechanisms and Their Impact on Project Performance. In C. Schwindt \& J. Zimmermann (Eds.), Handbook on Project Management and Scheduling Vol. 2 (pp. 1063-1078): Springer International Publishing.

Miura, K. (2005). Conservation of a 'living heritage site': A contradiction in terms? A case study of Angkor World Heritage Site. Conservation and Management of Archaeological Sites, 7(1), 3-18.

Murali, R. S. N. (2018, 9 July). Kampung Morten is where tourists to the historical city get a taste of local culture. The Star Online. Retrieved from https://www.thestar.com.my/metro/focus/2018/07/09/melakas-showcase-malayvillage-kampung-morten-is-where-tourists-to-the-historical-city-get-a-taste-o 
Indera Syahrul Mat Radzuan \& Yahaya Ahmad

Analysing Community Perceptions on Incentive Strategies in Safeguarding a Malay Heritage Village: The

Case of Kampung Morten, Melaka

Netherlands National Commission for UNESCO. (2014). Linking Universal and Local Values: Managing a Sustainable Future for World Heritage (2004). Amsterdam. 22-24 May 2003. Retrieved from http://whc.unesco.org/en/series/13/

Norsidah, U. (2020). Planning for a Redevelopment of a Traditional Urban Village of Kampong Bharu, Kuala Lumpur: A Challenge for a Sustainable Future. In H. Bougdah, A. Versaci, A. Sotoca, F. Trapani, M. Migliore, \& N. Clark (Eds.), Urban and Transit Planning: A Culmination of Selected Research Papers from IEREK Conferences on Urban Planning, Architecture and Green Urbanism, Italy and Netherlands (2017) (pp. 163-168). Cham: Springer International Publishing.Orbasli, A. (2002). Tourists in Historic Towns: Urban Conservation and Heritage Management. London: Taylor \& Francis.

Read, D. (2005). Monetary incentives, what are they good for? Journal of Economic Methodology, 12(2), 265-276.

Roberts, K. (2007). An Example of How Bennett's Hierarchy Can Be Used for Reporting. Melbourne, Australia: Roberts Evaluation Pty Ltd.

Roddewig, R. J. (1987). Economic Incentives for Historic Preservation. Washington D.C.: National Trust for Historic Preservation, Centre for Preservation Policy Studies.

Sharifah Mariam Alhabshi. (2010). Urban renewal of traditional settlements in Singapore and Malaysia: The cases of Geylang Serai and Kampung Bharu. Asian Survey, Vol. 50 (Issue 6), Nov/Dec 2010. pp 1135-1161.

Yeoh, B. S. A., \& Huang, S. (1996). The Conservation-redevelopment Dilemma in Singapore: The Case of the Kampong Glam Historic District. Cities, Vol. 13 (No. 6), pp 411-422.

Received: January 2020. Accepted: $1^{\text {st }}$ April 2020 